AGRARIS: Journal of Agribusiness and Rural Development Research

Vol. 3 No.1 Januari 2017
ESKA STEFANI ${ }^{1}$, RITA NURMALINA ${ }^{2}$, AMZUL RIFIN ${ }^{2}$

${ }_{1}^{1}$ Program Pascasarjana Magister Sains Agribisnis, FEM, IPB

${ }^{2}$ Departemen Agribisnis, FEM, IPB

eskafunnisa@gmail.com

\title{
Strategi Pegembangan Usaha Beras Hitampada Asosiasi Tani Organik Sawangan di Kabupaten Magelang
}

DOI: 10.18196/agr.3145

\section{ABSTRACT}

The black rice farming is potential to be developed in Indonesia for several reasons, for instance it is a rare local varieties, has many health benefit, high value, and feaseable to be developed based on farming analysis. Magelang regency is a region that has original varieties of black rice. The development of black rice farming was supported by Association of Sawangan Organic Farmers. This study applied internal and external environment analysis and formulated strategy using SWOT analysis, and then the priority strategy was chosen by weighting it based on SWOT analysis framework (A'WOT). Result showed that certified organic product was the most important factor on strength while the decreasing number of black rice farmer was the weakness. Furthermore, increasing people aware- ness on healty food was the opportunity and the threat was black rice has not been widely known in public. The priority alternative strategy that can be applied by Association of Sawangan Organic Farmers to develop black rice farming is to build a sustainable business partner.

Keywords: A'WOT, black rice, development strategy, Sawangan Organic Farmers Association

\section{INTISARI}

Usahatani beras hitam potensial untuk dikembangkan di Indonesia karenamemiliki varietas lokal yang masih jarang keberadaannya, mempunyai banyak manfaat kesehatan, nilai jual yang tinggi, dan layak dikembangkan berdasarkan analisis usahataninya.Kabupaten Magelang merupakan daerah yang mempunyai varietas asli padi beras hitam. Pengusahaan beras hitam di Kabupaten Magelang didukung salah satunya oleh Asosiasi Tani Organik Sawangan (TOS). Pada penelitian ini digunakan analisis lingkungan internal dan eksternal, perumusan strategi dengan menggunakan analisis SWOT kemudian prioritas strategi dilakukan dengan pembobotan melalui penyusunan hierarki berdasarkan kerangka SWOT (A'WOT). Analisis menunjukkan bahwa produk sudah bersertifikat organic merupakan subfaktor terpenting dari kekuatan; berkurangnya jumlah petani yang menanam beras hitsebagai kelemahan;meningkatnya kesadaran masyarakat akan kesehatan, sebagai peluang; sedangkan beras hitam belum banyak dikenal masyarakat, sebagai ancaman. Prioritas alternatif strategi yang dapat diterapkan pada Asosiasi Tani Organik Sawangan dalam mengusahakan beras hitam yang pertama adalah membangun mitra kerja yang kontinyu.

Kata kunci: Asosiasi Tani Organik Sawangan, A'WOT, beras hitam, strategi pengembangan

\section{PENDAHULUAN}

Beras mempunyai peranan penting dalam perekonomian Indonesia karena mempunyai kontribusi yang cukup besar terhadap PDB nasional, menciptakan 
lapangan kerja, meningkatkan pendapatan rumah tangga tani, dan merupakan makanan pokok penduduknya. Indonesia memiliki varietas beras yang beragam, salah satunya beras hitam yang mempunyai begitu banyak manfaat kesehatan.Beras hitam memiliki aroma yang baik dengan penampilan yang spesifik dan unik. Bila dimasak, nasi beras hitam berubah warna menjadi pekat dengan rasa dan aroma yang menggugah selera makan (Suardi dan Ridwan, 2009). Beras hitam banyak mengandung aleuron dan endospermia yang dapat memproduksi antosianin sehingga warna beras menjadi ungu pekat mendekati hitam. Selain antosianin, beras hitam juga mengandung kadar gula yang lebih sedikit, lebih banyak serat dan vitamin E (BPTP, 2010). Oleh sebab itu beras hitam sangat bermanfaat bagi kesehatan, antara lain sebagai antioksidan, sumber karbohidrat yang aman bagi penderita diabetes, baik untuk diet, serta mencegah penuaan dini pada kulit.

Beras hitam dikenal sebagai pangan fungsional, yaitu pangan yang secara alami atau melalui proses tertentu mengandung satu atau lebih senyawa yang dianggap mempunyai fungsi fisiologi yang bermanfaat bagi kesehatan (Kristamtini et. al.,2014). Kebutuhan masyarakat terhadap makanan tidak hanya untuk menghilangkan rasa lapar, tetapi juga dipercaya akan berkontribusi secara langsung terhadap kesehatan manusia, terutama untuk masyarakat yang berpendidikan atau masyarakat dengan tingkat ekonomi menengah keatas. Kebutuhan demikian akan berdampak pada peningkatan nilai jual dan permintaan bahan makanan atau produk-produk dengan label pangan fungsional. Pengetahuan dan pemahaman masyarakat tentang kesehatan disertai keinginan untuk menerapkan pola hidup sehat dengan memperbaiki pola diet atau asupan makanan yang lebih baik (Bech-Larsen dan Scholderer, 2007); memungkinkan pengembangan budidaya dan produksi beras hitam memiliki prospek ekonomi yang menjanjikan.

Realitas di lapangan menunjukkan beras hitam memiliki harga jual yang lebih tinggi dibandingkan dengan jenis beras lainnya. Ditingkat petani, harga gabah padi hitam mencapai 10.000 rupiah per kilo; ditingkat pengumpul mencapai 17.000 rupiah per kilo; ditingkat distributor mencapai 30.000 rupiah per kilo; bahkanditingkat pengecer dapat mencapai 58.000 rupiah per kilo. Selain itu, hasil penelitian Djatiharti dan Kristamtini (2009) mengungkapkan bahwa apabila dijual dalam bentuk gabah kering; beras hitam memiliki nilai B/C sebesar 1,39 dan nilai R/C 2,39. Jika dijual dalam bentuk beras, keuntungan akan meningkat dengan nilai $\mathrm{B} / \mathrm{C}$ sebesar 1,59 serta nilai $\mathrm{R} / \mathrm{C}$ sebesar 2,59. Hal ini menunjukkan beras hitam layak untuk diusahakan oleh petani, sehingga usaha beras hitam di Indonesia sangat potensial untuk dikembangkan.

Asosiasi Tani Organik Sawangan (TOS) merupakan kumpulan dari para petani di wilayah Sawangan yang peduli terhadap kesehatan dan lingkungan. Kepengurusan dipilih melalui musyawarah anggota pada 22 Oktober 2012 di Kantor Balai Penyuluhan Pertanian dan Kehutanan Kecamatan Sawangan, Kabupaten Magelang.Asosiasi dibentuk karena beberapa alasan, diantaranya Gapoktan tidak berjalan sebagaimana mestinya dan kondisi lahan pertanian yang kualitasnya semakin menurun akibat penggunaan pupuk kimia dan pestisida yang berlebihan.Asosiasi TOS mengembangkan beras hitam varietas Cempo Ireng yang merupakan varietas lokal Kabupaten Magelang.Kecamatan Sawangan merupakan daerah di Kabupaten Magelang,dengan jumlah petani yang mengusahakan beras hitam paling banyak ${ }^{1}$. Keberadaan asosiasi diharapkan dapat mendukung upaya pelestarian varietas lokal beras hitam. Asosiasi TOS berperan dalam membantu anggotanya memasarkan beras hitam serta mendukung dalam proses produksinya. Namun dalam menjalankan usaha beras hitam, asosiasi mengalami beberapa kendala yaitu jumlah petani anggota yang menanam beras hitam semakin sedikit. Hal ini disebabkan masa tanam beras hitam yang lebih lama dan produktivitasnya yang lebih rendah dibanding jenis padi yang lain. Masalah lain yang dihadapi asosiasi adalah jumlah penjualan semakin menurun. Oleh karena itu, Asosiasi Tani Organik Sawangan perlu mengembangkan strategi usaha dalam menyelesaikan berbagai permasalahan yang dihadapi.

Penelitian bertujuan menganalisis lingkungan internal dan eksternal Asosiasi Tani Organik Sawanganuntuk menetapkan prioritas alternatif strategi pengembangan usaha beras hitam.

\section{METODE PENELITIAN}

Penelitiandilakukan pada Asosiasi Tani Organik Sawangan (TOS) yang berlokasi di Kecamatan Sawangan, Kabupaten Magelang. Pertimbangan pemilihan lokasi yaitu: i) di Kecamatan Sawangandikembangkan varietas lokal beras hitam; ii)petani yang tergabung asosiasi merupakan pengembang beras hitam paling banyak di Kabupaten Magelang; iii) usaha asosiasi dalam mengembangkan beras hitam merupakan percontohan bagi lelompok tani di Kabupaten Magelang khususnya dalam pengusahaan beras hitam.

Pengumpulan data dilaksanakan pada bulan AprilDesember 2015.Data primer diperoleh melalui pengamatan langsung atau observasi, wawancara mendalam dengan 


\begin{tabular}{|c|c|c|c|c|}
\hline Langkah 1 & Langkah 2 & Langkah 3 & Langkah 4 & Langkah 5 \\
\hline $\begin{array}{c}\text { Analisis Faktor } \\
\text { SWOT }\end{array}$ & Strutur Hierarki & $\begin{array}{l}\text { Perbandingan } \\
\text { berpasangan (AHP) }\end{array}$ & $\begin{array}{l}\text { Matriks SWOT dan } \\
\text { Pengembangan strateg }\end{array}$ & $\begin{array}{l}\text { Matriks evaluasi } \\
\text { strategi }\end{array}$ \\
\hline $\begin{array}{l}\text { Identifikasi } \\
\text { Kekuatan, } \\
\text { Kelemahan, } \\
\text { Peluang dan } \\
\text { Ancaman }\end{array}$ & $\begin{array}{l}\text { Menyusun } \\
\text { struktur } \\
\text { hierarki dari level atas ke } \\
\text { bawah agar } \\
\text { dilakukan perbandingan } \\
\text { berpasangan } \\
\text { pada faktor SWOT dan } \\
\text { komponennya } \\
\text { sehingga terhubung } \\
\text { antara Tujuan } \\
\text { Utama (Goał) } \\
\text { terhadap faktor } \\
\text { dan subfaktor } \\
\text { SWOT, level } \\
\text { kriteria strategi } \\
\text { dan level } \\
\text { berikutnya. }\end{array}$ & $\begin{array}{l}\text { - Melakukan } \\
\text { perbandingan } \\
\text { berpasangan } \\
\text { antara subfaktor } \\
\text { SWOT pada setiap faktor } \\
\text { SWOT (Lokal } \\
\text { weight } \\
\text { - Secara } \\
\text { keseluruhan } \\
\text { prioritas } \\
\text { dihitung pada } \\
\text { masing-masing } \\
\text { faktor SWOT } \\
\text { (Global weight) }\end{array}$ & $\begin{array}{l}\text { - Menempatkan } \\
\text { prioritas } \\
\text { komponen SWOT ke } \\
\text { dalam matriks } \\
\text { SWOT } \\
\text { - Mengembang } \\
\text { kan strategi } \\
\text { dengan dua } \\
\text { faktor SWOT } \\
\text { yaitu strategi } \\
\text { SO, ST, WO, } \\
\text { WT. }\end{array}$ & $\begin{array}{l}\text { - Prioritas alternatif } \\
\text { strategi } \\
\text { - Perhitungan } \\
\text { consistency index }\end{array}$ \\
\hline
\end{tabular}

GAMBAR I. DIAGRAM ALIR METODE SWOT-AHP(TAKANO DAN WICKRAMASINGHE,2009)

sejumlah responden internal dan eksternal, serta pengisian kuesioner oleh responden dipandu peneliti.Responden internal antara lain ketua, sekretaris dan bendahara Asosiasi Tani Organik Sawangan; sedangkan responden eksternal terdiri dari PT Martani selaku distributor TOS, Dinas Pertanian Perkebunan dan Kehutanan Kabupaten Magelang, dan penyuluh pendamping TOS. Data primer yang diperoleh meliputi gambaran umum, visi, misi, tujuan, sasaran, serta informasi mengenai lingkungan internal dan eksternal dari Asosiasi Tani Organik Sawangan. Data sekunder diperoleh melalui study literature dari penelitian terdahulu, buku, jurnal, internet, dan literatur lain yang berhubungan dengan topik penelitian; serta penelusuran dokumen yang tersedia pada instansi terkait seperti Dinas Pertanian, Perkebunan dan

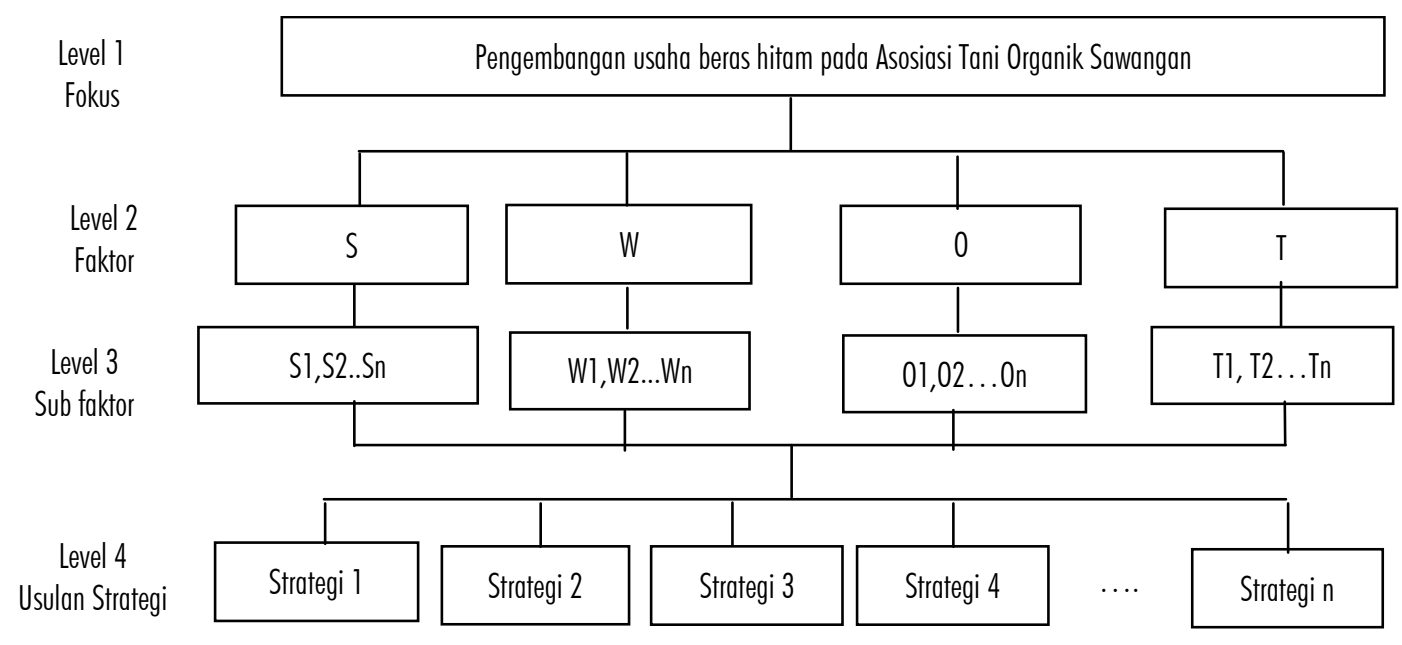


Kehutanan Kabupaten Magelang, dan BPPK Kecamatan Sawangan.

Analisis A'WOT digunakan untuk menemukan alternatif strategi pengembangan beras hitam, dengan tahapan-tahapan sebagaimana ditampilkan pada Gambar 1. Adapun perhitungannya dilakukan dengan software expert choice.

\section{Analisis faktor SWOT}

Analisis ini dilakukan untuk mengetahui kekuatan, kelemahan, peluang, dan ancaman Asosiasi Tani Organik Sawangan. Ketika menerapkan AHP standar, jumlah faktor kelompok SWOT dianjurkan tidak melebihi 10 faktor, karena jumlah dalam perbandingan berpasangan yang dibutuhkan akan berkembang.

\section{Menyusun struktur hierarki AHP}

Penyusunan hierarki dimulai dari persoalan yang akan diselesaikan dan diurai menjadi empat level (Gambar 2).

a. Level 1 merupakan tujuan yang ingin dicapai yaitu mengembangkan usaha beras hitam pada Asosiasi Tani Organik Sawangan.

b. Level 2 merupakan faktor-faktor yang diidentifikasi dalam analisis lingkungan internal dan eksternal yaitu strenght (S) atau kekuatan, weakness (W) atau kelemahan, opportunity $(\mathrm{O})$ atau peluang, dan threats $(\mathrm{T})$ atau ancaman.

c. Level 3merupakan faktor-faktor yang diidentifikasi dari masing-masing komponen SWOT yang diurai dalam S1, S2, Sn, W1, W2, Wn, O1, O2, On, T1, T2, Tn.

d. Level 4 adalah alternatif strategi yang akan dievaluasi dan dibandingkan sehingga diperoleh prioritas strategi.

\section{Perbandingan berpasangan}

a. Perbandingan berpasangan antara subfaktor SWOT pada setiap faktor SWOT

Pembobotan dilakukan terhadap faktor-faktor internal dan eksternal yang telah diperoleh dengan perbandingan berpasangan untuk mengetahui tingkat kepentingan faktor internal dan eksternal yang telah didapat dari kuesioner responden. Ketika melakukan perbandingan berpasangan, pertanyaan yang harus dijawab yaitu: i) dari dua subfaktor yang dibandingkan faktor mana yang memiliki dampak yang lebih tinggi (kekuatan, peluang, kelemahan atau ancaman); dan ii) seberapa besar dampaknya. Perbandingan ini sebagai masukan, prioritas relatif dari faktor-faktor lokal yang dihitung dengan menggunakan nilai eigen. Prioritas ini mencerminkan persepsi pengambil keputusan pada kepentingan relatif dari faktor. b. Perbandingan berpasangan antara faktor SWOT

Subfaktor dengan prioritas lokal tertinggi telah terpilih dari setiap faktor SWOT, kemudian bandingkan setiap faktor SWOT seperti tahap 3a. Perhitungan ini dilakukan untuk mendapatkan prioritas global. Hal ini dihasilkan dari perkalian antara prioritas lokal dengan nilai skala dari faktor SWOT. Jumlah dari semua prioritas global adalah satu.

\section{Formulasi strategi dengan matriks SWOT}

Pada tahap ini, perumusan strategi dilakukan dengan mencocokkan antara faktor internal dan eksternal. Faktor internal dan eksternal merupakan data yang telah diperoleh dari tahap input. Alat analisis yang digunakan pada tahap ini adalah matriks SWOT. Matriks SWOT terdiri dari komponen kekuatan (strengths), kelemahan (weakness), peluang (opportunities), dan ancaman (threats). Alternatif strategi disusun melalui kombinasi antara unsur-unsur tersebut (Gambar 3).

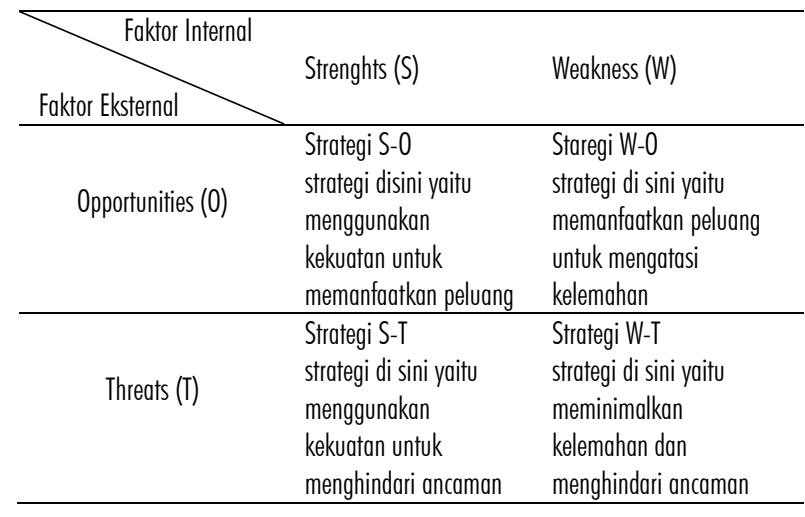

\section{GAMBAR 3. MATRIKS SWOT (WHEELEN DAN HUNGER, 2008)}

\section{Matriks evaluasi strategi}

AHP mengukur konsistensi menyeluruh dari berbagai pertimbangan melalui suatu rasio konsistensi (CR) dari indeks konsistensi $(\mathrm{CI})$ dengan nilai yang tepat. CI dirumuskan sebagai berikut:

$$
C I=\frac{\lambda \max -n}{n-1}
$$

"n" menyatakan jumlah kriteria/alternatif yang dibandingkan dan ë max adalah nilai eigen (eigen value) yang terbesar dari matriks perbandingan berpasangan orde n. Jika CI bernilai 0 maka keputusan penilaian tersebut bersifat perfectly consistent, dimana ë max sama dengan jumlah kriteria yang diperbandingkan yaitu $\mathrm{n}$. Semakin tinggi nilai CI semakin rendah tingkat kekonsistenan dari keputusan perbandingan yang telah dilakukan. 
TABEL I. NILAI RANDOM INDEX

\begin{tabular}{l|l|l|l|l|l|l|l|l|l|l|l|l|l}
\hline $\mathrm{N}$ & 1 & 2 & 3 & 4 & 5 & 6 & 7 & 8 & 9 & 10 & 11 & 12 & 13 \\
\hline $\mathrm{RI}$ & 0 & 0 & 0,58 & 0,90 & 1,12 & 1,24 & 1,32 & 1,41 & 1,45 & 1,49 & 1,51 & 1,48 & 1,56 \\
\hline \multicolumn{10}{c}{ Sumber: Marimin (2004) }
\end{tabular}

CI dapat dikatakan baik,jika CR tidak lebih 0,1. Jika CR lebih dari 0,1 maka mutu informasi tersebut harus diperbaiki, dengan cara menggunakan pertanyaan ketika membuat perbandingan berpasangan. Bila tindakan ini gagal, konsistensi dapat diperbaiki dengan peninjauan ulang persoalan yang tidak terstruktur secara tepat seperti dilakukan pada langkah 2 walaupun hanya bagian-bagian dari hierarki yang perlu diperbaiki. Rasio konsistensi (CR/consistency ratio) dirumuskan sebagai perbandingan antara consistency in dex (CI) dan random index (RI) dengan rumus sebagai berikut:

$$
C R=\frac{C I}{R I}
$$

Nilai RI untuk beberapa nilai $\mathrm{n}$ ditampilkan pada Tabel 1.

\section{HASIL DAN PEMBAHASAN}

\section{ANALISIS LINGKUNGAN INTERNAL DA EKSTERNAL}

Lingkungan internal merupakan lingkungan yang berada dalam asosiasi dan memiliki pengaruh langsung terhadap usahanya. Setiap perusahaan atau organisasi seperti halnya Asosiasi Tani Organik Sawangan mampu mengendalikan lingkungan internal. Analisis terhadap lingkungan internal merupakan proses yang dilakukan untuk mengidentifikasi kekuatan dan kelemahan asosiasi dengan dilihat dari aspek produksi, pemasaran, keuangan, manajemen, sistem informasi manajemen, serta penelitian dan pengembangan. Identifikasi kekuatan dan kelemahan dari masing-masing lingkungan internal dapat dilihat pada tabel 2.

Lingkungan eksternal merupakan lingkungan yang berada diluar asosiasi dan memiliki pengaruh terhadap usahanya. Analisis terhadap lingkungan eksternal merupakan proses yang dilakukan untuk mengidentifikasi peluang dan ancaman asosiasi dengan dilihat dari aspek ekonomi, sosial, budaya, demografi, dan lingkungan, politik, pemerintah dan hukum, teknologi serta aspek kompetitif. Identifikasi kekuatan dan kelemahan dari masing-masing lingkungan eksternal dapat dilihat pada tabel 3 .

\section{TABEL 2. IDENTIFIKASI FAKTOR STRATEGIS INTERNAL ASOSIASI TANI ORGANIK SAWANGAN}

\begin{tabular}{|c|c|c|}
\hline Lingkungan Internal & Kekuatan & Kelemahan \\
\hline 1.Produksi & $\begin{array}{l}\text { Tersedia Rice Milling Unit } \\
\text { (RMU) } \\
\text { Telah menerapkan pertanian } \\
\text { organik } \\
\text { Produk bersertifikat organik }\end{array}$ & $\begin{array}{l}\text { Berkurangnya petani } \\
\text { anggota yang menanam } \\
\text { beras hitam }\end{array}$ \\
\hline 2.Pemasaran & $\begin{array}{l}\text { Produk menawarkan banyak } \\
\text { manfaat kesehatan dan ramah } \\
\text { lingkungan }\end{array}$ & $\begin{array}{l}\text { Promosi belum maksimal } \\
\text { Kemasan masih } \\
\text { sederhana }\end{array}$ \\
\hline 3. Keuangan & & $\begin{array}{l}\text { Ketersediaan modal } \\
\text { terbatas }\end{array}$ \\
\hline 4.Manajemen & Pelatihan anggota & $\begin{array}{l}\text { Pengurus belum konsisten } \\
\text { menjalankan tugasnya } \\
\text { Administrasi kurang baik }\end{array}$ \\
\hline $\begin{array}{l}\text { 5.Penelitian dan } \\
\text { pengembangan }\end{array}$ & $\begin{array}{l}\text { Dapat melakukan pemurnian } \\
\text { benih sendiri }\end{array}$ & \\
\hline
\end{tabular}

\section{TABEL 3.IDENTIFIKASI FAKTOR STRATEGIS EKSTERNAL ASOSIASI TANI ORGANIK SAWANGAN}

\begin{tabular}{|c|c|c|}
\hline Lingkungan Eksternal & Peluang & Ancaman \\
\hline Ekonomi & $\begin{array}{l}\text { Industri pengolahan beras hitam } \\
\text { mulai berkembang } \\
\text { Program kredit dari bank }\end{array}$ & \\
\hline \multirow[t]{2}{*}{$\begin{array}{l}\text { Sosial, budaya, } \\
\text { demografi, lingkungan }\end{array}$} & $\begin{array}{l}\text { Meningkatnya kesadaran } \\
\text { masyarakat akan kesehatan } \\
\text { Lingkungan yang mendukung } \\
\text { pertanian organik }\end{array}$ & $\begin{array}{l}\text { Banyak masyarakat belum } \\
\text { mengetahui adanya beras } \\
\text { hitam dan manfaatnya }\end{array}$ \\
\hline & $\begin{array}{l}\text { Kab. Magelang memiliki daya } \\
\text { tarik wisata }\end{array}$ & Adanya hama burung \\
\hline Politik, pemerintahan & Adanya dukungan dari Dinas & \\
\hline dan hokum & Pertanian & \\
\hline Teknologi & $\begin{array}{l}\text { Adanya teknologi informasi } \\
\text { (internet) }\end{array}$ & \\
\hline Kompetitif & & $\begin{array}{l}\text { Persaingan dalam industri } \\
\text { semakin tinggi }\end{array}$ \\
\hline
\end{tabular}

\section{STRUKTUR HIERARKI AHP-SWOT}

Hierarki pada model AHP merupakan bagian yang penting, karena digunakan sebagai dasar bagi responden untuk memberikan pembobotan secara lebih sederhana. Dengan hierarki ini, permasalahan yang kompleks diharapkan dapat terlihat lebih sederhana dan mudah dipahami. Metode A'WOT merupakan penggunaan AHP dengan kerangka SWOT. Struktur hierarki tersusun dalam empat level (Gambar 4) yang terdiri dari:level pertama merupakan goal 


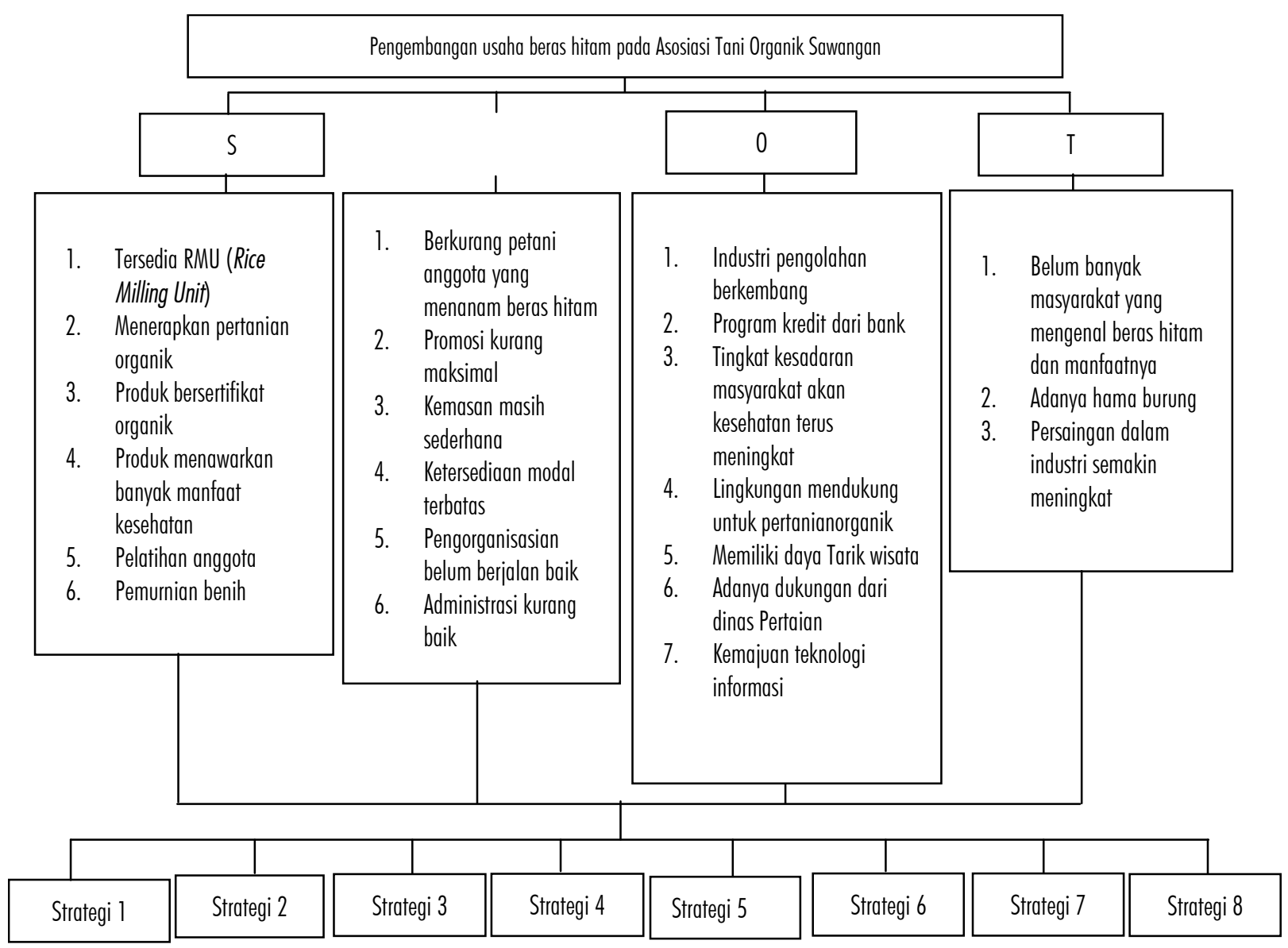

GAMBAR 4. PERSENTASI HIERARKI DARI ANALISIS A'WOT PADA ASOSIASI TANI ORGANIK SAWANGAN

atau tujuan, yaitu keputusan yang dijalankan dalam mengembangkan usaha beras hitam pada Asosiasi Tani Organik Sawangan; level kedua adalah kekuatan, kelemahan, peluang, dan ancaman pada faktor SWOT; level ketiga adalah subfaktor yaitu hasil dari analisis lingkungan internal dan eksternal asosiasi yang merupakan faktor kekuatan, kelemahan, peluang, dan ancaman; level keempat adalah alternatif strategi.

\section{PEMBOBOTAN BERPASANGAN}

Pembobotan dilakukan setelah menyusun hierarki seperti pada Gambar 4. Analisis pendapat gabungan para responden menunjukkan pembobotan pada level faktor menghasilkan bobot tertinggi pada faktor kekuatan dengan nilai 0,445 kemudian diikuti oleh peluang, kelemahan, dan ancaman dengan masing-masing nilai 0,393; 0,083; 0,079 dengan nilai inconsistency ratio 0,00385 . Hal ini menunjukkan bahwa penilaian tersebut telah memenuhi syarat perbandingan berpasangan karena nilai batas maksimum inconsistency ratio adalah 0,1. Kekuatan yang dimiliki Asosiasi TOS mempunyai bobot yang tertinggi, hal ini disebabkan Asosiasi TOS memiliki potensi yang besar dalam mengembangakan beras hitam. Asosiasi TOS didukung oleh beberapa hal seperti lingkungan yang mendukung untuk pertanian organik mengingat beras hitam lebih baik diproduksi secara organik, mempunyai RMU untuk pengolahannya, dan telah memiliki sertifikat organik. Kekuatan yang dimiliki oleh Asosiasi TOS akan menjadi modal tersendiri dalam menghadapi persaingan yang ada.

Pembobotan selanjutnya adalah pembobotan pada level subfaktor yang dilakukan dengan perbandingan berpasangan pada setiap subfaktor berdasarkan masing-masing kelompoknya, dimana nilai inconsistencyuntuk faktor kekuatan sebesar 0,02. Dari enam subfaktor yang ada, produk bersertifikat organik mempunyai nilai pembobotan tertinggi yaitu sebesar 0,277. Adanya sertifikat organik dapat menjadi jaminan bagi para konsumen bahwa produk yang dihasilkan telah diproduksi secara organik atau telah memiliki kriteria 
tertentu yang telah memenuhi standar organik. Untuk produk beras hitam, adanya sertifikat organik ini menjadi penting karena sering dipertanyakan oleh calon pembeli baik konsumen langsung maupun distributor, mengingat produk ini dikonsumsi untuk alasan kesehatan.Sebagaimana pendapat Djazuli (2014) bahwa manfaaat sertifikasi produk organik antara lain memberi jaminanproduk organik, melindungi konsumen dari penipuan, menjamin praktek perdagangan yang lebih adil, dan memberikan nilai tambah dan akses pasar.

Kelompok selanjutnya yang akan dibobotkan adalah faktor kelemahan. Faktor kelemahan terdiri dari berkurangnya jumlah petani yang menanam beras hitam, ketersediaan modal terbatas, promosi belum maksimal, kemasan masih sederhana, pengorganisasian belum berjalan baik, kemampuan administrasi rendah. Nilai inconsistency pada kelompok ini adalah 0,02 . Berkurangnya jumlah petani yang menanam beras hitam menjadi kelemahan dengan bobot tertinggi berdasarkan penilaian para responden yaitu sebesar 0,375 . Terus berkurangnya jumlah petani yang menanam beras hitamsangat berpengaruh pada proses pengembangan usaha beras hitam. Menurut responden terdapat beberapa hal yang menyebabkan petani enggan menanam beras hitam, yaitu: para petani merasa trauma karena pernah terjadi pelanggaran perjanjian dengan salah satu pihak distributor sehingga hasil produksi mereka tidak jadi dibeli oleh pihak distributor, dan tidak mudah untuk membangun kembali kepercayaan petani untuk menanam beras hitam.

Selain faktor internal, terdapat faktor eksternal yang berpengaruh pada pengembangan usaha beras hitam yaitu faktor peluang dan ancaman.Nilai inconsistencypada kelompok ini adalah 0,03.Menurut responden, semakin meningkatnya kesadaran masyarakat terhadap kesehatan menjadi faktor peluang yang paling tinggi, yaitu bernilai 0,251 . Beras hitam dinilai sebagai pangan fungsional yang memiliki banyak manfaat kesehatan merupakan alasan utama konsumen mengonsumsi beras hitam. Hal ini dapat menjadi peluang yang besar untuk memproduksi beras hitam.

Faktor eksternal lain yang akan dibobotkan adalah ancaman, dengan nilai inconsistency yaitu 0,00146. Adapun faktor-faktor yang dibandingkan penilaiannya adalah beras hitam belum banyak dikenal oleh masyarakat, adanya hama burung, serta persaingan dalam industri beras hitam semakin meningkat. Menurut responden,ancaman yang mempunyai nilai tertinggi adalah beras hitam belum banyak dikenal oleh masyarakat, yaitu sebesar 0,483. Hal ini menjadi ancaman paling besar yang harus diatasi agar semakin banyak orang yang mengonsumsi beras jenis ini dengan mengetahui manfaat beras hitam bagi kesehatan.

\section{ALTERNATIF STRATEGI PENGEMBANGAN}

Alternatif strategi disusun berdasarkan faktor-faktor internal, yaitu kekuatan dan kelemahan; serta faktor-faktor eksternal, yaitu peluang dan ancaman. Matriks SWOT menghasilkan alternatif strategi yang dikelompokkan menjadi empat strategi umum, yaitu SO, ST, WO, dan WT. Berdasarkan hasil analisis matriks SWOT (Gambar 5) terdapat sejumlah alternatif strategi yang dapat dipilih dalam pengembangan beras hitam pada Asosiasi TOS.

\section{STRATEGI S-0 (STRENGHTS-OPPORTUNITIES).}

Alternatif strategi SO merupakan strategi yang dirumuskan dengan mempertimbangkan kekuatan yang dimiliki Asosiasi TOS untuk dapat menfaatkan peluang yang ada. Strategi SO yang dapat dirumuskan adalah sebagai berikut.

1. Membangun mitra kerja secara continue dalam pemasaran produk [SO1]

Dalam upaya mengembangkan beras hitam diperlukan jaminan pasar bagi hasil produksi. Hal ini dapat dilakukan dengan menjalin kerjasama secara kontinyu, baik dengan dinas pemerintahan maupun dengan pihak distributor yang selama ini menjadi pasar bagi hasil produksi beras hitam.

Menjalin kerjasama dengan pihak Dinas Pertanian setempat menjadi sangat penting, mengingat Dinas Pertanian telah memberikan banyak bantuan seperti biaya untuk mendapatkan sertifikat organik, sampai dengan membantu memasarkan produk beras hitam melalui pameran-pameran. Disamping itu, membina kerjasama secara terus-menerus dengan distributor, retailerdan konsumen yang sudah menjadi pelanggan Asosiasi TOS sangat penting untuk dilakukan. Kerjasama yang dibangun sebaiknya didukung dengan $\mathrm{MoU}$ untuk setiap perjanjian yang dilakukan untuk mengantisipasi pelanggaran kontrak sebagaimana yang pernah terjadi sebelumnya.

\section{Memperluas jaringan pasar [SO2]}

Memperluas jaringan pemasaran untuk meningkatkan penjualan. Dengan kekuatan yang dimiliki Asosiasi TOS, yaitu produk yang ditawarkan banyak memberi manfaat kesehatan dan ramah lingkunganserta sudah memiliki sertifikat organik dapat digunakan untuk memperluas jaringan pasar dengan melihat peluang yang ada yaitu semakin tingginya tingkat kesadaran masyarakat akan kesehatan, semakin berkembangnya industri olahan beras hitam, serta 
TABEL 4. BOBOT PRIORITAS FAKTOR SWOT PENGEMBANGAN USAHA BERAS HITAM PADA ASOSIASI TANI ORGANIK SAWANGAN

\begin{tabular}{|c|c|c|c|c|}
\hline Faktor SWOT & Inconsistency & Sub faktor SWOT & $\begin{array}{l}\text { Bobot } \\
\text { global }\end{array}$ & Bobot lokal \\
\hline \multirow[t]{7}{*}{ Kekuatan } & 0,02 & & 0,445 & \\
\hline & & Tersedia RMU (rice milling unit) & 0,119 & 0,267 \\
\hline & & Menerapkan teknologi jajar legowo dan pertanian organic & 0,060 & 0,136 \\
\hline & & Produk bersertifikat organik & 0,124 & 0,277 \\
\hline & & Produk menawarkan banyak manfaat kesehatan & 0,089 & 0,201 \\
\hline & & Adanya pelatihan anggota & 0,025 & 0,055 \\
\hline & & Dapat melakukan pemurnian benih & 0,029 & 0,064 \\
\hline \multirow[t]{7}{*}{ Kelemahan } & 0,02 & & 0,083 & \\
\hline & & Berkurangnya jumlah petani yang menanam beras hitam & 0,031 & 0,375 \\
\hline & & Promosi belum maksimal & 0,009 & 0,113 \\
\hline & & Kemasan masih sederhana & 0,008 & 0,101 \\
\hline & & Ketersediaan modal terbatas & 0,017 & 0,207 \\
\hline & & Pengorganisasian belum berjalan baik & 0,011 & 0,136 \\
\hline & & Kemampuan administrasi rendah & 0,006 & 0,067 \\
\hline \multirow[t]{8}{*}{ Peluang } & 0,03 & & 0,393 & \\
\hline & & Industri pengolahan mulai berkembang & 0,059 & 0,151 \\
\hline & & Adanya kredit dari bank & 0,040 & 0,102 \\
\hline & & $\begin{array}{l}\text { Kesadaran masyarakat akan kesehatan semakin } \\
\text { meningkat }\end{array}$ & 0,099 & 0,251 \\
\hline & & Lingkungan mendukung untuk pertanian oraganik & 0,089 & 0,226 \\
\hline & & Kab Magelang mempunyai daya tarik wisata & 0,025 & 0,064 \\
\hline & & Adanya dukungan dari Dinas Pertanian & 0,041 & 0,105 \\
\hline & & Kemajuan teknologi & 0,039 & 0,100 \\
\hline \multirow[t]{4}{*}{ Ancaman } & 0,00146 & & 0,079 & \\
\hline & & Beras hitam belum banyak dikenal masyarakat & 0,038 & 0,483 \\
\hline & & Adanya hama burung & 0,032 & 0,403 \\
\hline & & Persaingan dalam industri beras hitam semakin tinggi & 0,009 & 0,114 \\
\hline
\end{tabular}

Kabupaten Magelang mempunyai daya tarik wisata. Dengan melihat beberapa peluang tersebut terdapat beberapa hal yang dapat dilakukan oleh Asosiasi TOS untuk meningkatkan penjualan, antara lain menawarkan produk ke rumah sakit. Khasiat kesehatan yang luar biasa memungkinkan beras hitam digunakan dalam proses pemulihan kesehatan. Selain itu, dengan daya tarik wisata yang dimilikiKabupaten Magelang, beras hitam dapat dikenalkan sebagai oleh-oleh khas daerah wisata. Produk tidak hanya dijual dalam bentuk beras, tetapi dapat dipasarkan dalam bentuk makanan olahan berbahan baku beras hitam.

\section{STRATEGI W-O (WEAKNESS-OPPORTUNITIES)}

Alternatif strategi WO merupakan strategi yang dirumuskan dengan melihat peluang untuk meminimalkan kelemahan yang dimiliki Asosiasi TOS. Berikut ini strategi WO yang dapat dirumuskan.

1. Memanfaatkan teknologi informasi untuk meningkatkan penjualan [WO1]

Beras hitam yang memiliki banyak manfaat kesehatan, belum banyak dikenal oleh masyarakat oleh karena itu membutuhkan upaya promosi yang lebih. Kemajuan teknologi informasi dan kemudahan untuk mengaksesnya dapat menjadi peluang yang dapat dimanfaatkan oleh Asosiasi TOS dalam mengatasi masalah promosi yang belum maksimal karena keterbatasan dana. Pemanfaatan aplikasi sosial media dalam promosi dapat dikembangkan mengingat mudah mengaksesnya dan tidak memerlukan biaya yang tinggi, dengan catatan tersedia SDM yang dapat mengelolanya.

2. Menguatkan kelembagaan Asosiasi TOS [WO2]

Manajemen yang dilakukan oleh Asosiasi TOS belum berjalan dengan baik oleh sehingga diperlukan penguatan kelembagaan. Asosiasi TOS perlu memperbaiki dan meningkatkan kemampuan administrasi, baik administrasi keuangan ataupun administrasi kegiatan bagi pengurus kelompok dan petani anggota. Selain itu, setiap pengurus yang tercatat dalam struktur organisasi belum dapat menjalankan tugasnya masing-masing. Padahal pembagian bidang-bidang pada kepengurusan sudah sangat baik. Perbaikan sistem manajemen harus dibuat berdasarkan kesepakatan bersama agar pelaksanaannya dapat berjalan secara partisipasif. Untuk dapat meningkatkan partisipasi pengurus diperlukan 


\begin{tabular}{|c|c|c|}
\hline & $\begin{array}{l}\text { Kekuatan (Strenght) } \\
\text { 1.Tersedia Rice Milling Unit(RMU) } \\
\text { 2.Menerapkan pertanian organik } \\
\text { 3.Produk bersertifikat organik } \\
\text { 4.Produk menawarkan banyak manfaat } \\
\text { kesehatan } \\
\text { 5.Adanya pelatihan bagi anggotanya } \\
\text { 6.Dapat melakukan pemurnian benih }\end{array}$ & $\begin{array}{l}\text { Kelemahan (Weakness) } \\
\text { 1.Berkurangnya petani yang menanam beras } \\
\text { hitam } \\
\text { 2.Promosi kurang maksimal } \\
\text { 3. Kemasan masih sederhana } \\
\text { 4. Ketersediaan modal terbatas } \\
\text { 5.Pengorganisasian belum berialan baik } \\
\text { 6.Administrasi kurang baik }\end{array}$ \\
\hline $\begin{array}{l}\text { Peluang (Opportunity) } \\
\text { 1.Industri pengolahan beras hitam semakin } \\
\text { berkembang } \\
\text { 2.Program kredit dari bank } \\
\text { 3. Tingkat kesadaran masyarakat akan } \\
\text { kesehatan terus meningkat } \\
\text { 4. Lingkungan yang mendukung untuk } \\
\text { pertanian organik } \\
\text { 5. Kab Magelang memiliki daya tarik wisata } \\
\text { 6.Adanya dukungan dari Dinas Pertanian } \\
\text { 7. Kemajuan teknologi informasi }\end{array}$ & $\begin{array}{l}\text { Strategi S-0 } \\
\text { [SOI] Membangun mitra kerja yang continue } \\
\text { dalam pemasaran produk } \\
(\mathrm{S} 1, \mathrm{~S} 2, \mathrm{~S} 3, \mathrm{~S} 5,01,05,06)\end{array}$ & $\begin{array}{l}\text { Strategi W-0 } \\
\text { [W01] memanfaatkan teknologi informasi } \\
\text { untuk meningkatkan penjualan (W2, 07) } \\
\text { [W02] Menguatkan kelembagaan Asosiasi } \\
\text { TOS (W1, W5, W6, 06) } \\
\text { [W03] meningkatkan ketersediaan modal } \\
(\text { W4, 02) }\end{array}$ \\
\hline $\begin{array}{l}\text { Ancaman (Threath) } \\
\text { 1. Banyak masyarakat yang belum } \\
\text { mengetahui beras hitam dan manfaatnya } \\
\text { 2.Adanya hama burung } \\
\text { 3.Persaingan dalam industri semakin } \\
\text { meningkat }\end{array}$ & $\begin{array}{l}\text { Strategi S-T } \\
\text { [STI] Mengembangkan produk beras hitam } \\
\text { dengan optimalisasi sumberdaya yang ada } \\
\text { untuk memenangkan persaingan }(S 5, T 3)\end{array}$ & $\begin{array}{l}\text { Strategi W-T } \\
\text { [WTI] mengembangkan produk dengan } \\
\text { penelitian dan pengembangan (W1, T2) } \\
\text { [WT2] memperbaiki kemasan produk untuk } \\
\text { meningkatkan dayasaing produk (W3, } \mathrm{Tl}, \mathrm{T} \text { ) }\end{array}$ \\
\hline
\end{tabular}

\section{GAMBAR 5. MATRIKS SWOT ASOAISAI TANI ORGANIK SAWANGAN DALAM MENGUSAHAKANBERAS HITAM}

pengendalian dan motivasi. Pengendalian dapat dilakukan dengan membuat aturan dan SOP secara tertulis terkait dengan proses produksi sampai dengan pemasaran serta dilengkapi dengan evalusai dan adanya punishment jika terjadi pelanggaran. Perbaikan manajemen ini memerlukan bantuan dari Dinas Pertanian Kabupaten Magelang melalui pendampingan maupun pelatihan manajemen untuk memperbaiki kelembagaannya.

\section{Meningkatkan ketersediaan modal dengan kredit [WO3]}

Dalam mengembangkan usaha beras hitam keterbatasan modal merupakan salah satu kendala yang dihadapi Asosiasi TOS. Namun, saat ini terdapat bank milik negara yang berlokasi di wilayah Sawangan menawarkan kredit usaha pertanian. Hal ini tentu saja harus dimanfaatkan Asosiasi TOS secara rasionla dalam memperoleh tambahan modal.

\section{STRATEGI S-T (STRENGHTS-THREATS)}

Alternatif strategi ST merupakan strategi yang dirumuskan dengan menggunakan kekuatan yang dimiliki Asosiasi TOS untuk meminimalkan ancaman yang ada. Strategi ST yang dapat dirumuskan adalahmengembangkan produk beras hitam dengan mengoptimalkan sumber daya yang ada untuk memenangkan persaingan [ST]

\section{TABEL 5. URUTAN PRIORITAS STRATEGI PENGEMBANGAN USAHA BERAS HITAM PADA ASOSIASI TANI ORGANIK SAWANGAN}

\begin{tabular}{|c|c|c|c|}
\hline Tipe strategi & Alternatif strategi & Bobot & Prioritas \\
\hline $\mathrm{S}-\mathrm{O}$ & $\begin{array}{l}\text { Membangun mitra kerja yang } \\
\text { continuedalam pemasaran produk }\end{array}$ & 0,326 & 1 \\
\hline$S-0$ & Memperluas jaringan pasar & 0,148 & 3 \\
\hline W-0 & $\begin{array}{l}\text { Memanfaatkan teknologi untuk } \\
\text { meningkatkan penjualan }\end{array}$ & 0,135 & 4 \\
\hline W-0 & Menambah modal & 0,045 & 7 \\
\hline W-0 & $\begin{array}{l}\text { Menguatkan kelembagaan Asosiasi } \\
\text { TOS }\end{array}$ & 0,163 & 2 \\
\hline S-T & $\begin{array}{l}\text { Mengembangkan produk dengan } \\
\text { optimalisasi sumberdaya yang } \\
\text { dimiliki }\end{array}$ & 0,100 & 5 \\
\hline W-T & $\begin{array}{l}\text { Pengembangkan produk dengan } \\
\text { penelitian dan pengembangan }\end{array}$ & 0,052 & 6 \\
\hline W-T & $\begin{array}{l}\text { Memperbaiki kemasan untuk } \\
\text { meningkatkan daya saing }\end{array}$ & 0,031 & 8 \\
\hline
\end{tabular}

Peningkatan penjualan dapat dilakukan dengan pengembangan produk yang dapat dilakukan dengan memanfaatkan sumber daya yang dimiliki secara optimal guna meningkatkan nilai jual produk ditengah persaingan yang ada saat ini. Grading dapat dilakukan untuk menjaga kualitas dari beras hitam yang dijual. Beras hitam dengan grade yang baik dapat dipasarkan melalui distributor retailer, rumah sakit 
bahkan hotel-hotel; sedangkan beras hitam dengan grade yang kurang baik dapat dijual ke konsumen akhir atau diolah menjadi produk turunannya agar produk beras hitam dapat memberikan nilai tambah.

\section{STRATEGI W-T (WEAKNESS-THREATS)}

Alternatif strategi WT merupakan strategi yang dirumuskan untuk meminimalkan kekurangan dan menghindari ancaman yang dimiliki Asosiasi TOS. Strategi WT yang dapat dirumuskan sebagai berikut.

1. Mengembangkan produk beras hitam dengan penelitian dan pengembangan [WT1]

Penelitian dan pengembangan yang perlu dilakukan oleh Asosiasi TOS terkait dengan benih beras hitam yang memiliki masa tanam 120 hari. Sebaiknya dilakukan penelitian lebih lanjut melalui bekerjasama dengan instansi pendidikan atau instansi pemerintah agar masa tanamnya dapat lebih pendek. Disamping itu, habitus tanaman beras hitam yang tinggi sehingga petani menghadapi kesulitandalam pengendalian hama burung, merupakan kelemahan yang harus diperbaiki dalam perbaikan benih.

2. Memperbaiki kemasan produk untuk meningkatkan daya saing [WT2]

Kemasan produk merupakan hal yang penting untuk mendukung penjualan. Selama ini kemasan produk beras hitam di Asosiasi TOS masih sederhana. Hanya dikemas dengan plastik kemudian ditempel stiker logo Asosiasi. Jika ingin menembus pasar yang lebih besar perlu didukung dengan kemasan yang menarik. Beras hitam sendiri merupakan produk organik yang sangat mudah diserang kutu, hal ini bisa diatasi dengan kemasan vacum. Selain itu banyaknya masyarakat yang belum mengetahui kandungan beras hitam, akan lebih mengedukasi masyarakat jika diberi keterangan kandungan gizi beras hitam serta cara untuk memasaknya. Serta diberi keterangan takaran dalam memasak, karena beras hitam ini lebih banyak membutuhkan air dalam memasak jika dibanding dengan beras putih karena hanya pecah kulit saja.

\section{ANALISIS PRIORITAS STRATEGI}

Prioritas strategi dilakukan pada delapan alternatif strategi yang telah didapatkan dari kombinasi SWOT. Pada tahap ini diberikan nilai pada setiap alternatif strategi untuk menentukan prioritas utama yang harus didahulukan. Dari hasil perbandingan berpasangan diperoleh overall inconsistency bernilai 0,02 . Alternatif strategi yang paling utama dilakukan adalah perbaikan kelembagaan dan memperluas pasar. Dengan demikian pengembangan usaha beras hitam di
Asosiasi Tani Organik Sawangan akan lebih mudah untuk dijalankan. Dengan jangkauan pasar yang lebih luas dan terjamin, petani akan termotivasi untuk menanam beras hitam.

\section{KESIMPULAN}

Prioritas alternatif strategi yang dapat diterapkan pada Asosiasi Tani Organik Sawangan dalam mengusahakan beras hitam, mulai dari prioritas pertama sampai kedelapan adalah: i) membangun mitra kerja yang continue,ii) menguatkan kelembagaan, iii) memperluas jaringan pasar, iv) memanfaatkan teknologi untuk meningkatkan penjualan, v) mengembangkan produk dengan memanfaatkan sumberdaya yang ada, vi) mengembangkan produk dengan penelitian, vii) pengembangan, menambah modal dengan kredit, serta viii) memperbaiki kemasan untuk meningkatkan daya saing.

Saran yang dapat dijadikan masukan untuk Asosiasi Tani Organik Sawangan yaitu sebaiknya asosiasidapat menerapkan alternatif strategi yang ada dan menjalankan berdasarkan prioritasnya.

\section{DAFTAR PUSTAKA}

Bech-Larsen T., \&Scholdere J. 2007. Functional foods in Europe: consumer reasearch, market experiences and regulatory aspects. Journal Trends in Food Science \&Technology18: 231-234

Balai Pengkajian Teknologi Pertanian Yogyakarta[BPTP].2010. kelebihan beras hitam sebagai pangan fungsional.[diakses pada 27 Desember 2015]. Tersediapada: http://yogya.litbang.pertanian.go.id

Djatiharti, A., \& Kristamtini. 2009. Potensi usahatani padi beras hitam melik di Kabupaten Bantul Yogyakarta. Prosiding Seminar Nasional Hasil Penelitian Padi 2009: Inovasi Teknologi Padi untuk Mempertahankan Swasembada dan Mendorong Ekspor Beras: 1281-1286.

Djazuli, M. 2014. Manfaat dan proses sertifikasi pertanian organik. [diunduh pada 17 April 2016]. Tersedia pada:http:// www.balittro.litbang.pertanian.go.id

Kristamtini, Taryono, Basunanda, P.,\& Murti, R. H. 2014. Keragaman genetik dan korelasi parameter warna beras dan kandungan antosianin total sebelas kultivar padi beras hitam lokal. Jurnal Ilmu Pertanian 1(17): 90-103.

Marimin. 2004. Pengambilan Keputusan: Kriteria Majemuk. PT Gramedia Widiasarana Indonesia, Jakarta.

Suardi, D., \& Ridwan, I. 2009. Beras hitam, pangan berkhasiat yang belum populer. http://www.pustaka.litbang.pertanian.go.id/.[1 Maret 2015]

Takano, S., \& Wickramasinghe, V. 2009. Application of combined SWOT and analytic hierarchy process (AHP) for tourism revival strategik marketing planning: a case of Sri Lanka Taoursm. Journal of the Eastern Asia Society for Transportation Studies 8(2009).

Wheelen, T. L.,\& Hunger, J. D. 2008. Strategic Management and Business Policy: Concept and Cases Edisi 11. Pearso Education Inc, New Jersey. 